\title{
Effect of Silicon Carbide and Titanium Hydride on the Foamability of Aluminum Alloy (6061)
}

\author{
Mohammad M. Hailat \\ Department of Chemical Engineering, Albalqa Applied University, Alhuson, Jordan \\ Email:mhailat@bau.edu.jo
}

How to cite this paper: Hailat, M.M. (2017) Effect of Silicon Carbide and Titanium Hydride on the Foamability of Aluminum Alloy (6061). Journal of Materials Science and Chemical Engineering, 5, 1-11. https://doi.org/10.4236/msce.2017.56001

Received: April 30, 2017

Accepted: June 9, 2017

Published: June 12, 2017

Copyright $\odot 2017$ by author and Scientific Research Publishing Inc. This work is licensed under the Creative Commons Attribution International License (CC BY 4.0).

http://creativecommons.org/licenses/by/4.0/

(c) (i) Open Access

\begin{abstract}
Aluminum foam is a light weight material with good mechanical and energy absorption properties. In this study, aluminum foam composite was fabricated using aluminum powder 6061 and silicon carbide $(\mathrm{SiC})$ powder. Titanium hydride $\left(\mathrm{TiH}_{2}\right)$ was used as the foaming agent. Cold compact followed by hot pressing (sintering) was used to produce the composite precursor. Foaming was carried out, following the sintering process, by heating the aluminum composite precursor to a temperature above the melting point of aluminum (Al). The linear expansion of the foam and the percent porosity were found to increase as the $\mathrm{SiC}$ percentage decreased from 10 to $4 \%$, whereas the density got lower. The percent porosity and linear expansion were both found to increase as the percentage of the foaming agent was increased from 0.5 to $1.5 \%$. Compression stress was evaluated for two different porosity values ( $40 \%$ and $47 \%$ ), and found to be higher for the samples with lower percent porosity at the same strain value. Effect of shape memory alloy fiber, made of nickel and titanium (NiTi), on the mechanical properties was also investigated. The compression stress was higher, in the densification region, for the samples in which NiTi was used.
\end{abstract}

\section{Keywords}

Aluminum Foam, Composite, Silicon Carbide, Titanium Hydride

\section{Introduction}

Due to the unique properties such as light weight, high stiffness and high energy absorption combined with good acoustic properties, aluminum foam, open and closed cells, is becoming an important material for energy absorption applications [1] [2]. It is a porous material with very low density, high strength and capable of converting the energy of impact into plastic energy and absorbs most of it at low stress [3] [4] [5] [6]. In addition to the good energy absorption during 
impact, aluminum foam also can exhibit stress wave attenuation, therefore, they prevent propagation of stress waves.

Several different manufacturing techniques and foaming processes, to produce closed-cell aluminum foam, have been utilized and reported in the literature. In a process, patented by Alcan International Limited, a gas, air or nitrogen, is injected into the aluminum melt to produce the foam [7]. The gas is trapped inside and produces closed cells foam upon quenching the liquid metal. In another process, developed in Japan and known by Alporas process, a blowing agent, titanium hydride $\left(\mathrm{TiH}_{2}\right)$ is mixed with the aluminum melt to form a homogenous foam mixture [8]-[13]. The decomposition of the $\mathrm{TiH}_{2}$ releases hydrogen gas that causes expanding of the aluminum melt and forming of the metal foam. Using the powder metallurgy compacting technique, patented by Fraunhofer CMAM, is another process in which the aluminum powder and the foaming agent are pre-mixed, cold compacted, and then sintered at a temperature below the decomposition temperature of the $\mathrm{TiH}_{2}$ to form what is called foamable precursor [14]. The precursor then can be heated at a temperature above the melting point of the aluminum, releasing the hydrogen gas, and forming the aluminum foam [15].

The powder metallurgy fabrication technique is the process that was used in this research to produce the aluminum foam and aluminum foam composite. Induction heating was utilized to provide the heat necessary and produce the precursor. A good precursor density is important for the post foaming process. Therefore, it is necessary to have the right temperature and pressure during production of the precursor or the sintering process.

The incorporation of shape memory alloy fiber (SMA) into the aluminum matrix as a reinforcement, as demonstrated by a work previously done utilizing the same process, exhibited an increase in the absorbed impact energy, the absorbed energy during an impact test was almost three times of aluminum (Figure 1) [16]. Therefore, a tougher aluminum composite was produced upon reinforcing the aluminum matrix with about $5 \%$ vol. SMA fiber and $5 \%$ wt. SiC. The design concept of the tough-aluminum was based on using the shape recovery to induce the reverse phase transformation in order to create compressive residual stress inside the composite. Inducing compressive stress through shape memory effect is the reason behind the strengthening mechanism exhibited by the tough-aluminum composite. To explore their potential of increasing the absorbed energy and enhancing the impact toughness, SMA fiber was also incorporated in the aluminum foam in this investigation.

To enhance the ballistic properties, aluminum foam composite can be integrated with other material that has good ballistic properties, such as ceramics for example. Therefore, to obtain both good ballistic properties and high energy absorption, aluminum foam composite could be integrated with either a ceramic layer or a SMA-aluminum layer. For higher performance, the aluminum foam could also be sandwiched between the ceramic layer and the SMA-aluminum layer. Such kind of integration or hybrid material system could be utilized to 


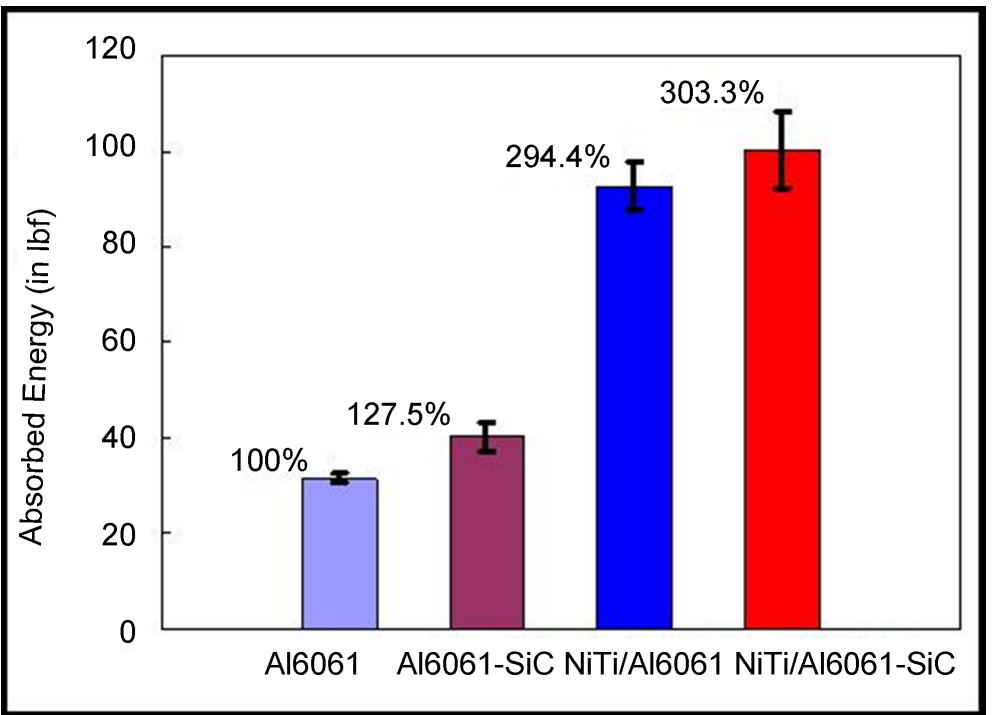

Figure 1. Absorbed energy for aluminum and different aluminum composites [16].

build light weight structural armors.

The mechanical properties of the aluminum foam can be controlled by controlling its porosity. However, controlling the porosity and, consequently, reproducing the mechanical properties is still a difficulty facing the foam researchers. In this article aluminum foam and NiTi-reinforced aluminum foam composite were produced and their potential as energy absorption materials was investigated through evaluation some of their mechanical properties.

\section{Materials and Method of Fabrication}

The aluminum foam composite was produced using the powder metallurgy fabrication technique. Aluminum powder alloy 6061, supplied by Valimet Inc., with particle size-30 micron and chemical composition given in weight percent, presented in Table 1, was used as the main foam matrix component. The foaming agent utilized, was a powder supplied by the Atlantic Equipment Engineering (AEE), with an average particle size-200 mesh with more than $98.8 \%$ titanium hydride $\left(\mathrm{TiH}_{2}\right)$. The other components of the foaming agent and their weight percentages are given in Table 2.

The production of the aluminum composite started with making a homogenous mixture of aluminum powder (6061), silicon carbide ( $\mathrm{SiC}$ ) and titanium hydride $\left(\mathrm{TiH}_{2}\right)$, this was achieved by means of a laboratory scale roller mixer, supplied by Fasco Industries Inc. type U63 model 71637283. It is important to have a uniform foaming agent distribution or a homogenous mixture, nonuniform $\mathrm{TiH}_{2}$ distribution could lead to a nonuniform cell sizes. Effect of the silicon carbide was investigated by changing its loading percentage from $4 \%$ to $10 \%(4,5$, 6,7 and $10 \%$ wt.), whereas, effect of the titanium hydride was investigated through changing its percentage between $0.5 \%$ and $1.5 \%(0.5 \%, 0.6 \%, 0.7 \%, 1 \%$ and $1.5 \%$ wt.). The homogenous powder mixture was loaded in a stainless steel 
Table 1. Aluminum alloy powder (6061) chemical composition.

\begin{tabular}{ccccccccc}
\hline $\mathrm{Al}$ & $\mathrm{Cr}$ & $\mathrm{Cu}$ & $\mathrm{Fe}$ & $\mathrm{Mg}$ & $\mathrm{Mn}$ & $\mathrm{Si}$ & $\mathrm{Ti}$ & $\mathrm{Zn}$ \\
\hline Balance & 0.08 & 0.27 & 0.26 & 0.97 & 0.02 & 0.56 & 0.02 & 0.05 \\
\hline
\end{tabular}

Table 2. Foaming agent $\left(\mathrm{TiH}_{2}\right)$ chemical composition.

\begin{tabular}{cccccc}
\hline TiH2 & Oxygen & Nitrogen & Carbon & Iron & Other Impurities \\
\hline$>98.8$ & 0.31 & 0.013 & 0.018 & 0.089 & 0.05 \\
\hline
\end{tabular}

mold designed and machined specifically for this purpose. The mold with the powder mixture inside was slowly pressed using a MTS machine up to $220 \mathrm{MPa}$ in order to compact the powder mixture (cold compact) and preparing it for sintering. The mold was then heated, using induction heating, to a temperature of $445^{\circ} \mathrm{C}$ and held at this temperature for 30 minutes, during this time the pressure was kept at $220 \mathrm{MPa}$ for sintering to take place. A thermocouple was inserted in the middle of the upper punch to monitor the temperature as close as possible to the sample. After sintering, the mold with the aluminum composite sample precursor inside, was quenched in water at room temperature, then the sample was removed from the mold. The demolding process was carried out by pushing the sample through the mold by the same MTS machine after placing the mold on top of a hollow cylinder. To carry out the foaming process, the precursor was then placed inside another cylindrical mold that has a diameter a litthe bit $(0.5 \mathrm{~mm})$ larger than the one that was used for producing the precursor. The mold with the sample inside was placed in a preheated furnace at a temperature of $750^{\circ} \mathrm{C}$, which is above the melting point of aluminum, in order to allow the decomposition of the $\mathrm{TiH}_{2}$, and releasing the hydrogen gas that was used to drive the foaming process. The sample was left in the furnace for 12 minutes. After taking the mold out of the furnace, it was quenched in water from outside. No water was allowed to touch the sample directly. Some cracks were developed in the samples that directly touched the water. Figure 2 exhibits a schematic diagram of the foam fabrication stages.

Shape memory alloy fibers were added to some samples to investigate their effect on the absorbed energy. It was super elastic nickel-titanium (NiTi) alloy (Nitinol SE508), supplied by NDC Nitinol Devices and Components. Its diameter was 0.011 inch. It was chopped into a length of about $5 \mathrm{~mm}$, the surface was cleaned with a nitric acid solution to remove the coating layer covering the surface. Surface etching and exposing the surface of the fiber can enhance the chemical reaction between aluminum and titanium, and consequently, could lead to enhancing and strengthening the intermetallic bond, and the adhesion between the aluminum matrix and the fiber [16] [17].

To produce a two-layer of metal matrix hybrid composite comprises an aluminum foam composite ( $\mathrm{Al}$ and $\mathrm{SiC}$ ) layer and metal-matrix composite ( $\mathrm{Al}+$ $\mathrm{SiC}+\mathrm{NiTi}$-fiber) layer, a mixture of aluminum powder, $\mathrm{SiC}$ and SMA fiber was first loaded at the bottom of the mold then another mixture consist of aluminum 


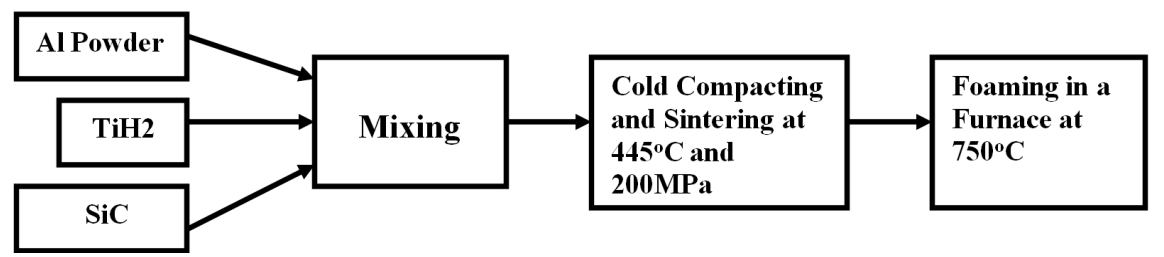

Figure 2. Schematic diagram of the foam fabrication stages.

powder, SiC and foaming agent was loaded on top of it. The two mixtures were separated by a thin sheet of aluminum foil. After sintering a one piece of precursor was produced as shown in Figure 10, then the precursor was post heated at $750^{\circ} \mathrm{C}$ for 12 minutes to initiate the foaming process.

\section{Results and Discussion}

The aluminum precursor produced, after sintering and before foaming, had the dimensions of about $31.3 \mathrm{~mm}$ in diameter and a height of about $14.5 \mathrm{~mm}$. After heating to a temperature above the melting point of aluminum, it expanded, and the linear expansion percentage varied with the $\mathrm{SiC}$ and $\mathrm{TiH}_{2}$ loading contents. Figure 3 shows the aluminum composite before and after foaming.

\subsection{Effect of Silicone Carbide (SiC) on Porosity}

Effect of $\mathrm{SiC}$ on the linear expansion was studied by varying the percentage of $\mathrm{SiC}$ in the powder mixture between $4 \%$ and $10 \%$. It was found that the largest linear expansion did occur at the lowest $\mathrm{SiC}$ percentage utilized (4\%), and it was about $134 \%$. Evidently, and as it can be clearly seen in Figure 4, the linear expansion increased as the percentage of $\mathrm{SiC}$ decreased from $10 \%$ to $4 \%$. As a result of increasing the linear expansion, the cell size did get larger, thus the cell size was inversely proportional with the percentage of the $\mathrm{SiC}$ weight percent. As a result of varying the cell size, the density of the foam varied as well, and it did decrease from 1.2 to $1 \mathrm{~g} / \mathrm{cm}^{3}$. Since the porosity is expected to affect the mechanical properties of the foam, controlling the amount of $\mathrm{SiC}$ in the mixture is vital, and consequently, could be utilized to control the properties of the foam.

\subsection{Effect of Titanium Hydride $\left(\mathrm{TiH}_{2}\right)$ on Porosity}

Effect of the amount of the foaming agent used was also investigated by varying its weight percentage between $0.5 \%$ and $1.5 \%$. It was found to have a profound effect on the linear expansion; as the percentage of the foaming agent increased from $0.5 \%$ to $1.5 \%$, linear expansion increased as well, and consequently, the porosity increased and as a result the density decreased, this is clearly demonstrated in Figure 5. To delay the earlier decomposition of the blowing agent, it could be passivated; a process by which an oxide layer could be produced around the $\mathrm{TiH}_{2}$ particles. This could be achieved by preheating the $\mathrm{TiH}_{2}$ in air prior to mixing with the aluminum powder.

Having the right sintering conditions, as mentioned above, is a key factor in the post foaming process. Some preliminary results indicated that using the right 


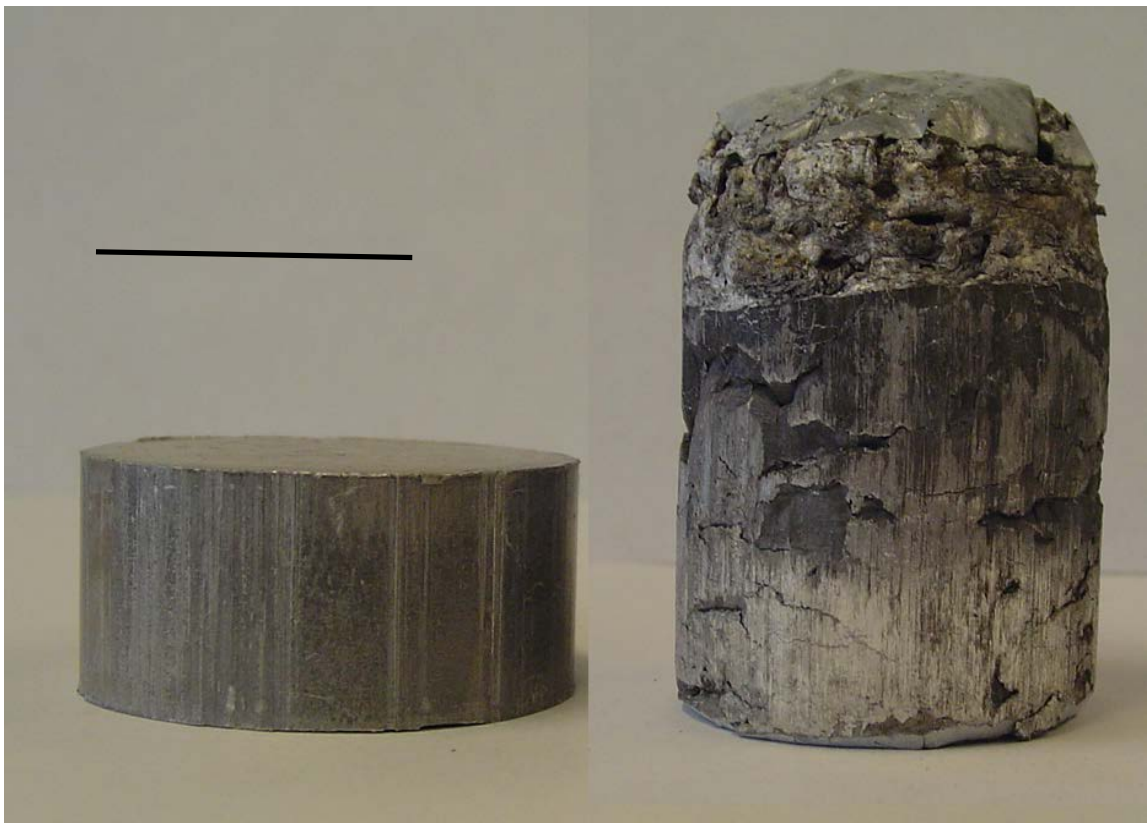

Figure 3. Aluminum composite sample before and after foaming.

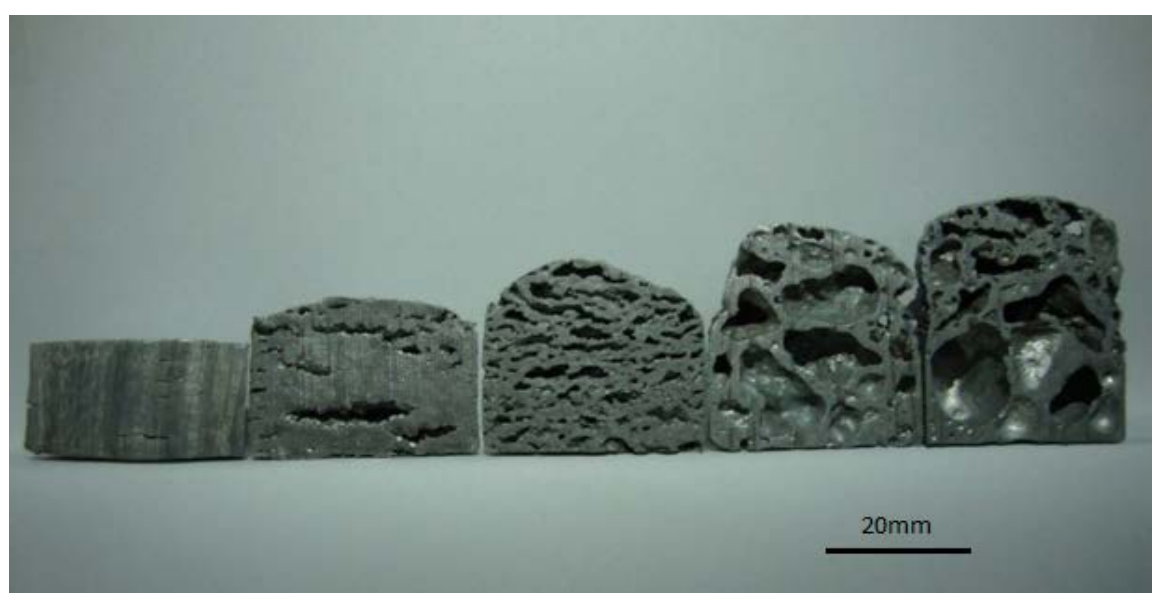

Figure 4. Effect of $\mathrm{SiC}$ percentage (left to right: 10, 7, 6, 5 and 4\%) on the linear expansion of aluminum foam.

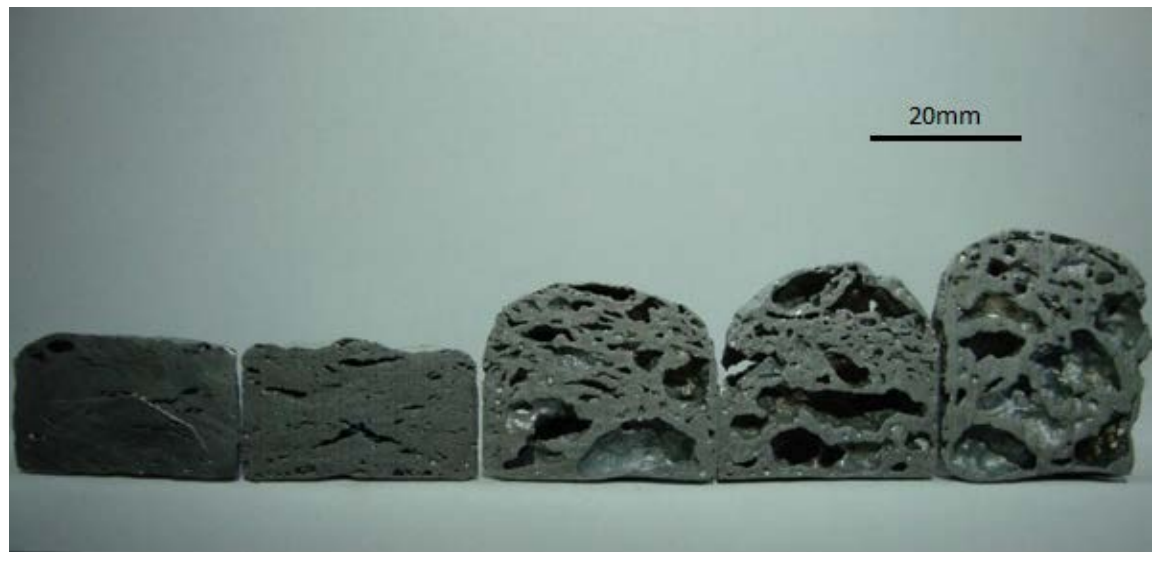

Figure 5. Effect of the $\mathrm{TiH}_{2}$ weight percent (left to right: 0.5, 0.6, 0.7, 1.0 and 1.5\%) on the liner expansion of aluminum foam. 
conditions can produce a precursor with a density suitable for foaming. Precursor with low density is an indication of voids existence which could results in poor heat transfer inside the precursor, and consequently, longer time is needed for melting and foaming. It also could increase the chance of oxidation which means higher melting temperature.

\subsection{Effect of Porosity on the Compressive Strength of Aluminum Foam}

The ability of aluminum foam composites to absorb energy was assessed preliminarily through conducting compression test. Samples with a diameter of 32.9 $\mathrm{mm}$ and height of $20 \mathrm{~mm}$, with and without SMA fibers, were machined from the original foam samples using electrical discharge machining (EDM). They were tested using a MTS testing machine at cross-head speed of $2 \mathrm{~mm} / \mathrm{min}$. The surface skin was retained from one side (bottom side). Both types of samples tested (with and without SMA fiber) did contain 5\% wt. SiC. Figure 6 exhibits the shape and size of the compression test samples. Although the samples were cut from different foam batches, but the fabrication procedure, experimental conditions and materials were all the same. The engineering compression stress-strain curves are presented in Figure 7. Porosity percentage (pct) is the difference between the two curves. The lower one has a percent porosity $\left(\mathrm{P}_{\mathrm{f}}\right)$ of $47.6 \%$ and a density of $1.36 \mathrm{~g} / \mathrm{cm}^{3}$, whereas the upper curve has a relatively lower percent porosity value $(40 \%)$ and higher density $\left(1.6 \mathrm{~g} / \mathrm{cm}^{3}\right)$. The stress-strain curves can be divided into three regions: linear elastic, collapse, and densification region. In the first region, the deformation is elastic due to cell wall bending. In the second region, plastic collapse of the first cell wall occurs and the modulus drop while

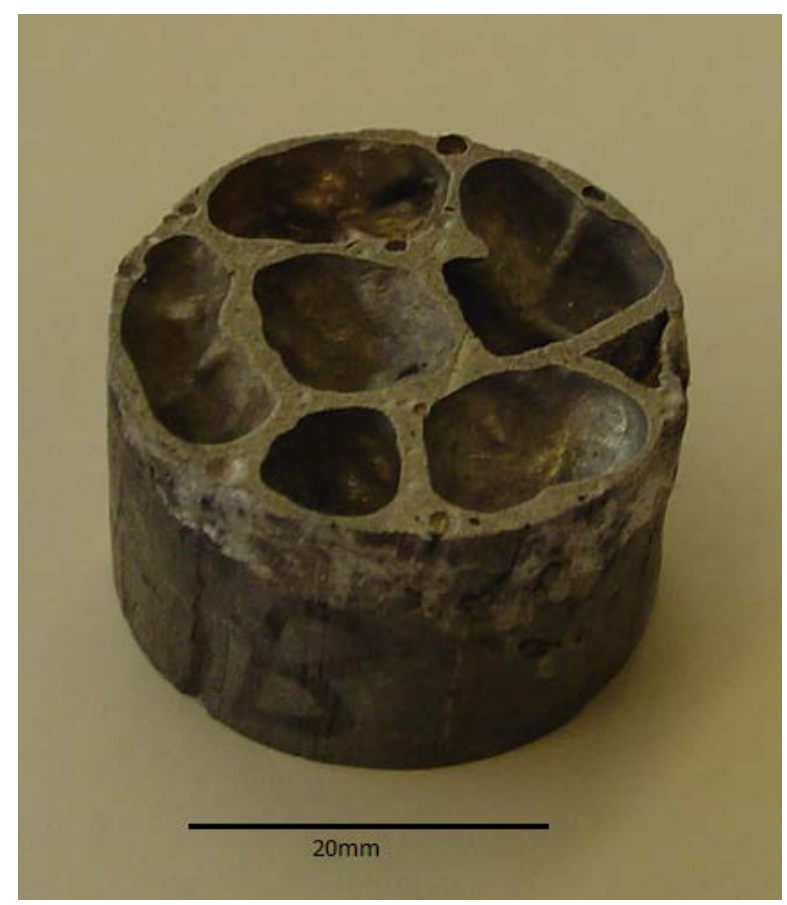

Figure 6. Aluminum foam test sample for compression test. 


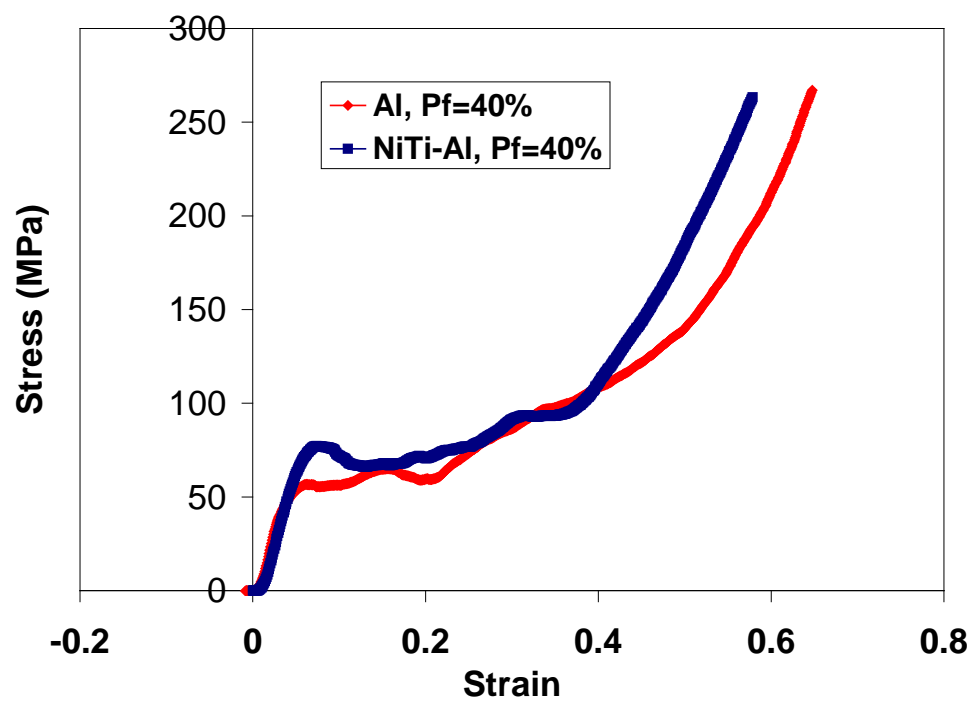

Figure 7. Stress-strain behavior of aluminum foam composite for different porosity values.

the specific stress keeps almost plateau or slightly increased up to $50 \%$ in the case of the higher $P_{f}$ sample. The sample with the smaller $P_{f}$ value (40\%) experienced an increase in the stress with the strain in the same region until about $50 \%$ strain. Evidently the stress-strain curve of the sample with lower porosity and higher density, topped the stress-strain curve of the sample with higher porosity. The higher stress for the sample with lower porosity, in the third region, is because the deformation becomes highly localized and preceded by the advance of a densification front to the undeformed regions.

\subsection{Effect of Shape Memory Alloy Fiber on the Compressive Strength of Aluminum Foam}

Figure 8 represents the stress-strain curves for aluminum foam and NiTi-reinforced aluminum foam. The porosity in the two cases was the same $\left(P_{f}=40\right)$. The upper curve represents the aluminum foam sample without NiTi fiber, whereas the lower curve represents the NiTi-reinforced aluminum foam sample. The sample reinforced with the NiTi fiber exhibited a higher elastic modulus and a higher stress in the densification region than the sample without NiTi fiber. Therefore, effect of the NiTi fiber on the compressive strength appeared mainly in the first and third region. The second region, the collapse region, was almost identical. This is due to the fact that this region results mainly from the collapse of the aluminum foam cells.

A scanning electron micrograph of the fiber in the aluminum matrix is given in Figure 9. Evidently there is a good adhesion and interfacial bonding between the fiber and the matrix. Since the foaming process was conducted at a high temperature $\left(750^{\circ} \mathrm{C}\right)$, a chemical reaction between aluminum and Titanum at the fiber surface, to form $\mathrm{Al}_{\mathrm{x}} \mathrm{Ti}_{\mathrm{y}}$, may took place. This chemical reaction could be responsible for the strong interfacial bonding. 


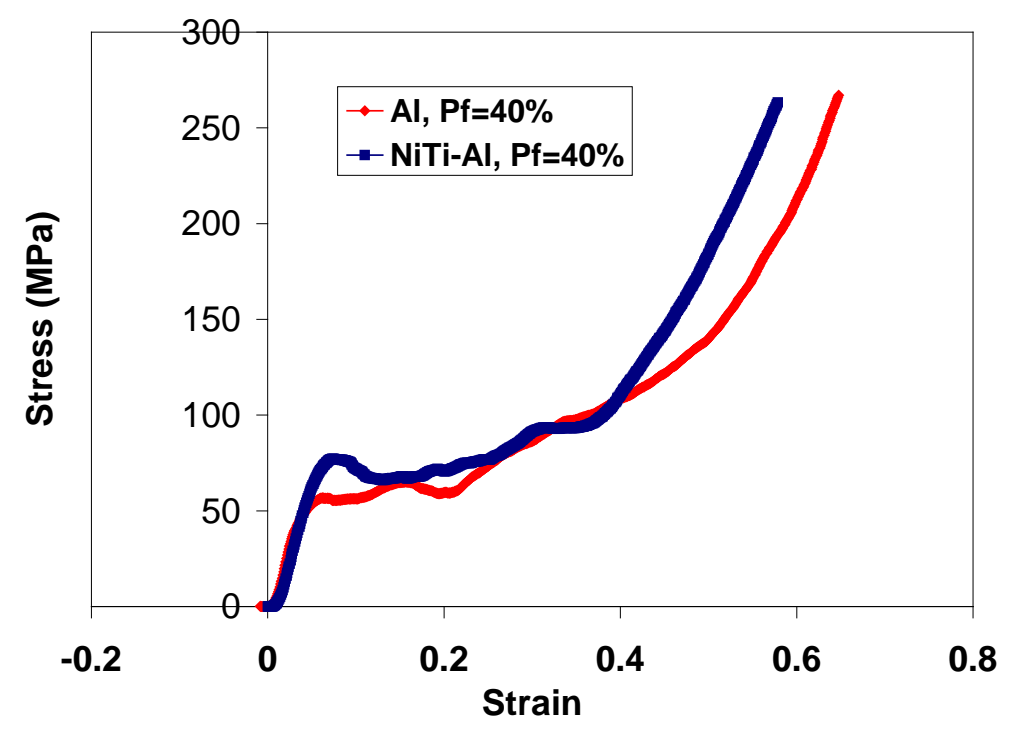

Figure 8. Stress-strain behavior of aluminum foam and NiTi-reinforced aluminum foam composite, both having the same porosity $\left(\mathrm{P}_{\mathrm{f}}=40 \%\right)$

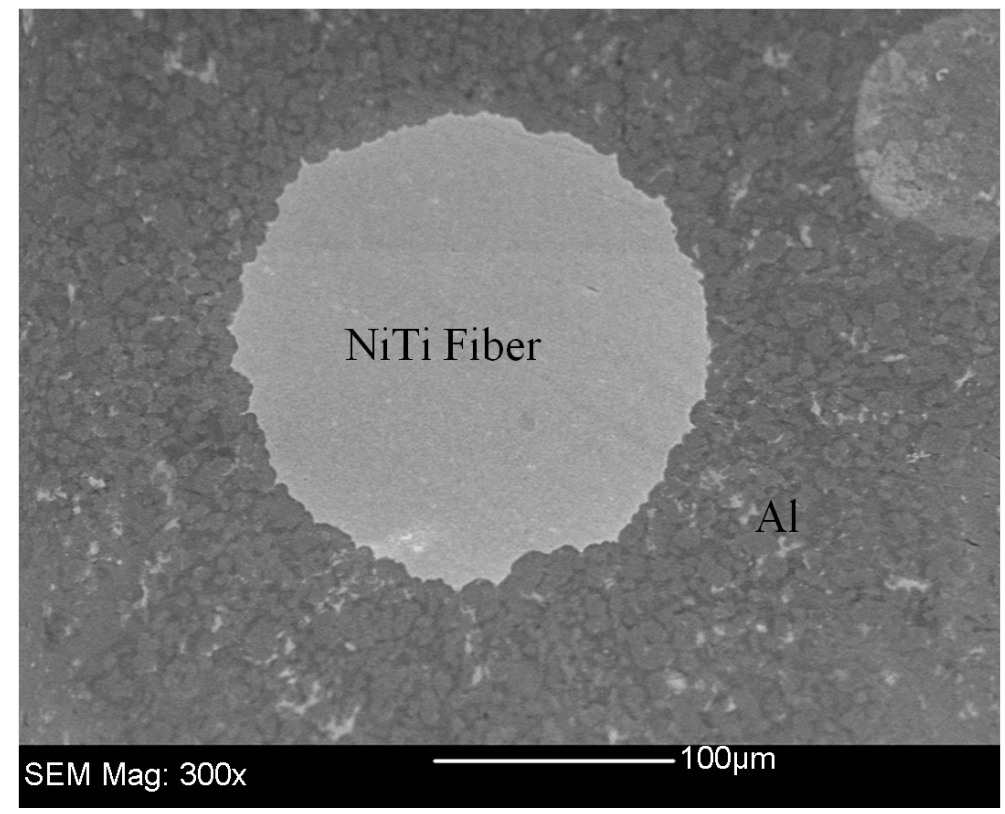

Figure 9. NiTi-reinforcement fiber in the aluminum matrix composite.

Figure 10 represent the metal matrix hybrid composite. Since the top part contains a foaming agent, it did expand and produced aluminum foam (Figure 10) on top of the metal matrix composite (MMC). The two layers were well bonded. The advantage of such kind of hybrid system could be used to serve the purpose of energy absorption and ballistic protection combined.

\section{Conclusions}

In this investigation, aluminum foam and NiTi-reinforced aluminum foam composite were successfully produced. The foam composite was reinforced with $\mathrm{SiC}$ and shape memory alloy fiber (Nitinol SE508). Both reinforcements have 


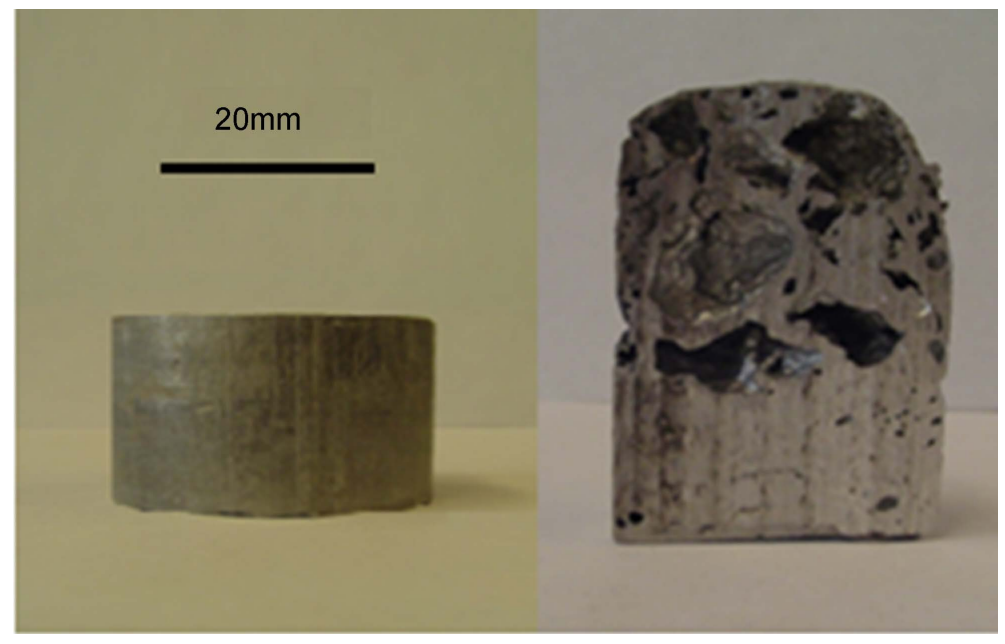

Figure 10. MMC and aluminum foam composite hybrid system (left: before foaming, right: after foaming).

contributed positively to the mechanical properties of the aluminum foam composite. It has been found that the linear expansion increases with decreasing the amount of the SiC. A $5 \%$ wt. was the loading content used to produce the foam samples utilized in the testing. The compression test results indicated that the yield stress and the stress in both the collapse and densification region was higher for the lower porosity fraction or higher density foam. The shape memory alloy did contribute to the yield stress and the stress in the densification region. Although NiTi-reinforced samples showed a little higher stress in the collapse region, it was not significant, this is due to that fact the stress resistance in this region is mainly due to the collapse of the foam cells. Higher levels of fiber percentages in the foam need to be investigated. The stress-strain curves in Figure 8 demonstrate the strengthening effect produced by SMA short fibers upon incorporation in the aluminum foam composite. This is expected to increase the energy absorbing capacity of the composite under compressive loading.

Hybrid system of NiTi-reinforced aluminum (MMC) and aluminum foam composite ( $\mathrm{Al}$ foam and $\mathrm{SiC}$ ) was also successfully produced, however, its mechanical properties were never investigated. This system could be used as part of armor for energy absorption and ballistic protection.

\section{References}

[1] Banhart, J. (2001) Manufacturing, Characterization and Application of Cellular Metals and Metal Foams. Progress in Materials Science, 46, 559-632. https://doi.org/10.1016/S0079-6425(00)00002-5

[2] Gibson, L.J. (2000) Mechanical Behavior of Metallic Foams. Annual Review of Material Science, 30, 191-227. https://doi.org/10.1146/annurev.matsci.30.1.191

[3] Santosa, S., Wierzbicki, T., Hanssen, A.G. and Langseth, M. (2000) Experimental and Numerical Studies of Foam-filled Sections. International Journal of Impact Engineering, 24, 509-534. https://doi.org/10.1016/S0734-743X(99)00036-6

[4] Hanssen, A.G., Langseth, M. and Hopperstad, O.S. (2000) Static and Dynamic Crushing of Circular Aluminum Extrusions with Aluminum Foam Filler. International Journal of Impact Engineering, 24, 475-507. 
https://doi.org/10.1016/S0734-743X(99)00170-0

[5] Seitzberger, M.F., Rammerstorfer, G.H., Degischer, P. and Gradinger, R. (1997) Crushing of Axially Compressed Steel Tubes Filled with Aluminum Foam. Acta Mechanica, 125, 93-105. https://doi.org/10.1007/BF01177301

[6] Aktay, L., Toksoy, A.K. and Guden, M. (2006) Quasi-static Axial Crushing of Extruded Polystyrene Foam-filled Thin-Walled Aluminum Tubes: Experimental and Numerical Analysis. Material \& Design, 27, 556-565.

https://doi.org/10.1016/j.matdes.2004.12.019

[7] Jin, I., Kenny, D.L. and Sang, H. (1990) Method of Producing Lightweight Foamed Metal. US Patent No. 4973358.

[8] Deqing, W. and Ziyuan, S. (2003) Effect of Ceramic Particles on Cell Size and Wall Thickness of Aluminum Foam. Materials Science and Engineering A, 361, 45-49. https://doi.org/10.1016/S0921-5093(03)00557-4

[9] Yang, C.C. and Nakae, H. (2003) The Effect of Viscosity and Cooling Conditions on the Foamability of Aluminum Alloy. Journal of Materials Processing Technology, 141, 202-206. https://doi.org/10.1016/S0924-0136(02)01048-8

[10] Song, Z., Zhu, J., Ma, L. and He, D. (2001) Evolution of Foamed Aluminum Structure in Foaming Process. Journal of Materials Science and Engineering A, 298, 137 143. https://doi.org/10.1016/S0921-5093(00)01285-5

[11] Ma, L. and Song, Z. (1998) Cellular Structure Control of Aluminum Foams during Foaming Process of Aluminum Melt. Scripta Materialia, 39, 1523-1528. https://doi.org/10.1016/S1359-6462(98)00361-3

[12] Ip, S.W., Wang, Y. and Toguri, J.M. (1999) Aluminum Foam Stabilization by Solid Particles. Canadian Metallurgical Quarterly, 38, 81-92.

https://doi.org/10.1179/cmq.1999.38.1.81

[13] Babcsan, N., Leitlmeier, D. and Degischer, H.P. (2003) Foamability of Particle Reinforced Aluminum Melt. Materialwissenschaft und Werkstofftechnik, 34, 22-29. https://doi.org/10.1002/mawe.200390011

[14] Baumeister, J. and Schrader, H. (1992) Methods for Manufacturing Foamable Metal Bodies. US Patent No. 5151246.

[15] Gergely, V. and Clyne, B. (2002) The FORMGRIP Process: Foaming of Reinforced Metals by Gas Release in Precursors. Advanced Engineering Materials, 2, 175-178. https://doi.org/10.1002/(SICI)1527-2648(200004)2:4<175::AID-ADEM175>3.0.CO; $\underline{2-\mathrm{W}}$

[16] Xie, C.L., Hailat, M., Abedin, Z., et al. (2007) Development of Short Fiber Reinforced NiTi/Al 6061 Composite. Journal of Engineering Materials and Technology, 129, 69-81. https://doi.org/10.1115/1.2400271

[17] Chauldhury, Z., Hailat, M., Lue, Y. and Newaz, G. (2011) Aluminum-Based Composites Reinforced with SiC Particles and NiTi Fibers: Influence of Fiber Dimensions and Aging Time on Mechanical Properties. Journal of Materials Science, 46, 1945-1955. https://doi.org/10.1007/s10853-010-5030-2. 
Submit or recommend next manuscript to SCIRP and we will provide best service for you:

Accepting pre-submission inquiries through Email, Facebook, LinkedIn, Twitter, etc. A wide selection of journals (inclusive of 9 subjects, more than 200 journals)

Providing 24-hour high-quality service

User-friendly online submission system

Fair and swift peer-review system

Efficient typesetting and proofreading procedure

Display of the result of downloads and visits, as well as the number of cited articles Maximum dissemination of your research work

Submit your manuscript at: http://papersubmission.scirp.org/

Or contact msce@scirp.org 